\title{
TYC5594-576-1: R-PROCESS ENRICHMENT METAL-POOR STAR
}

\author{
T. V. Mishenina ${ }^{1}$, I. A. Usenko², A. Yu. Kniazev ${ }^{3}$, V. V. Kovtyukh ${ }^{1}$ \\ ${ }^{1}$ Astronomical Observatory, Odessa National University, Odessa 65014-UA, Ukraine, \\ tmishenina@ukr.net,vkovtyukh@ukr.net \\ 2 Mykolaiv Astronomical Observatory Research Institute, Observatorna 1, Mykolaiv 54030-UA, \\ Ukraine,igus99@ukr.net \\ 3 Southern African Large Telescope Foundation, South African Astronomical Observatory, \\ P.O. box 9, 7935 Observatory, Cape Town, South Africa, a_kniazev@saao.nrf.ac.za
}

ABSTRACT. Atmospheric parameters and elemental abundances of metal-poor Population II star TYC5594576-1 $([\mathrm{Fe} / \mathrm{H}]=-2.8)$ have been studied, including the elements of neutron (n-) capture processes, as an important part of the enrichment sources of early Galaxy. $\mathrm{Na}, \mathrm{Mg}, \mathrm{Al}, \mathrm{Co}, \mathrm{Sr}, \mathrm{Y}, \mathrm{Zr}, \mathrm{Mo}, \mathrm{Ba}, \mathrm{La}, \mathrm{Ce}, \mathrm{Pr}, \mathrm{Sm}, \mathrm{Eu}$, Gd, Dy, Os, and Th abundances were determined using the synthetic spectrum method, taken into account the hyperfine structure (HFS) for the Ba II, La II and Eu II lines. The abundances of $\mathrm{Si}, \mathrm{Ca}, \mathrm{Sc}, \mathrm{N}$ were determined based on the equivalent widths of their lines. The carbon abundance was obtained by the molecular synthesis fitting for the $\mathrm{CH}$ region of 4300-4330 $\AA \AA$. For the abundances determinations of $\mathrm{C}, \mathrm{Na}, \mathrm{Mg}, \mathrm{Al}, \mathrm{Ba}$, and Th the NLTE corrections have been applied.

We have determined the abundances of several ncapture elements for the first time and found that the behaviour of these elements abundances shows a significant trend with increasing atomic number. The elements ratios of $[\mathrm{Eu} / \mathrm{Fe}]=1.85,[\mathrm{Ba} / \mathrm{Eu}]=-1.24,[\mathrm{Sr} / \mathrm{Ba}]=-1.04$ confirm the status of TYC5594-576-1 as a r-process enrichment star, with lower strontium $[\mathrm{Sr} / \mathrm{Fe}]=-0.33$ and higher thorium $[\mathrm{Th} / \mathrm{Fe}]=1.28$ abundances. The obtained europium and thorium excesses testifies to the early enrichment of the Galaxy by the r-process elements as a result of the merger of neutron stars or black holes. The carbon abundance confirms the effect of canonical additional mixing in this star.

Keywords: stars: abundances - stars: atmospheres - stars: Population II - stars: individual (TYC5594-576-1).

АНОТАЦІЯ. Для відтворення раннього збагачення Галактики хімічними елементами та тестування теорій нуклеосинтезу важливим є дослідження елементів, що утворювалися в результаті процесів захоплення нейтронів n. Елементи швидкого захвату n (r-процес) можуть бути створені як результат, наприклад, злиття нейтронних зірок або впливу магнітного полю в магнітогідродинамічних наднових. Це також важливо для відстеження шляху збагачення цими елементами міжзоряного середовища в ранні галактичні часи. Для зірки ТYC5594-576-1 з металічністю $[\mathrm{Fe} / \mathrm{H}]=-2,8$ були визначені атмосферні параметри та розповсюдженність елементів в їі атмосфері.

Спектральний матеріал отримано за допомогою ешеле-спектрографа HRS Південноафриканського великого телескопа (SALT) у режимі середньої роздільної здатності ( $\mathrm{R} \sim 31000-41000)$ з високим коефіцієнтом відношення сигнал до шуму, близько 100-200, в діапазоні довжин хвиль від 3900 до 8700 Å̊. Для визначення атмосферних параметрів та хімічного складу зірки ТYС5594-576-1 був застосовано наближення ЛТР (локальної термодинамічної рівноваги) з використанням моделей атмосфери Castelli \& Kurucz (2004). Вмісти $\mathrm{Na}, \mathrm{Mg}$, $\mathrm{Al}, \mathrm{Ni}, \mathrm{Co}, \mathrm{Sr}, \mathrm{Y}, \mathrm{Zr}, \mathrm{Mo}, \mathrm{Ba}, \mathrm{La}, \mathrm{Ce}, \mathrm{Pr}, \mathrm{Sm}, \mathrm{Eu}, \mathrm{Gd}, \mathrm{Dy}$, Os, Th розраховані 3 використанням нової версії програмного забезпечення STARSP (Tsymbal, 1996), враховуючи надтонку структуру (HFS) для ліній Eu II, a вміст $\mathrm{Si}, \mathrm{Ca}, \mathrm{Sc}$ визначений 3 використанням єквівалентних ширин i WIDTH9 Р. Куруча. Вміст вуглецю розраховано за допомогою порівняння розрахунків молекулярного синтезу до спостережного спектру в області СН (4300-4330 ̊̊)).

Для вмісту $\mathrm{C}, \mathrm{Na}, \mathrm{Mg}, \mathrm{Ba}$ та Th ми розглянули оцінки поправок за рахунок відхилення від ЛТР.

Ми вперше визначили вміст деяких елементів нейтронного (n) захвату, включно 3 торієм, для ТYС5594-576-1 . Ми виявили, що поведінка вмісту nелементів показує ріст ї вмістів зі збільшенням атомного номера, а також співвідношення елементів $[\mathrm{Eu} / \mathrm{Fe}]=1.90,[\mathrm{Ba} / \mathrm{Eu}]=-1,19$ відповідає визначенню досліджуваної зірки як зірки зі збагаченням r-процесу. Ми отримали вміст торію зі значенням $[\mathrm{Th} / \mathrm{Fe}]=1.26$. Отриманий надлишок європію і торію свідчить про раннє збагачення Галактики елементами r-процесу у результаті злиття нейтронних зірок або чорних дір. Вміст вуглецю підтверджує ефект канонічного додаткового змішування (Denissenkov \& Pinsonneault 2008) у досліджуваній зірці. 


\section{Introduction}

Metal-deficient $([\mathrm{Fe} / \mathrm{H}]<-1.0)$ stars investigations can provide an information about the early nucleosynthesis for the Galaxy, especially about the same of rare elements, produced from early neutron star mergers (NSM) or/and supernovae (SN), and also about the chemical evolution of the Galaxy in the whole.

Investigations of the stars enrichment by the fast (r-) neutron capture process elements are very important for understanding of the early Galaxy chemical evolution (Sneden et al. 1996, Yong et al. 2013, Roederer et al. 2014, Hansen et al. 2018).

The sources of of r-process elements production are in the matter of researches and discussions now. There are some considerations that strongly support an early mergers of neutron stars (NSM) hypotheses (e.g. Lattimer \& Schramm 1974, Rosswog et al. 2014, Lippuner et al. 2017). At that, standard core-collapse supernovae (CCSNs) most likely cannot produce the basic elements of the r-process (Arcones \& Thielemann 2013); however, the most likely candidate for yet another r-process formation site could be core-collapsed supernovae with a strong magnetic field (e.g. Winteler et al. 2012, Nishimura et al. 2017).

Beers \& Christlieb (2005) proposed that the r-processenhanced, metal-poor stars to be divided into two main categories: the r-I stars have $0.3<=[\mathrm{Eu} / \mathrm{Fe}]<=+1.0$, while r-II stars have $[\mathrm{Eu} / \mathrm{Fe}]>+1.0$; both require $[\mathrm{Ba} / \mathrm{Eu}]<0$ to avoid contamination from the s-process.

Variations in the lighter neutron-capture elements, such as $\mathrm{Sr}, \mathrm{Y}$, and $\mathrm{Zr}$, have been observed in several stars (e.g., Spite et al. 2018) and a new limited r-process designation with $[\mathrm{Sr} / \mathrm{Ba}]>+0.5$ to classify stars with enhancements in these lighter elements was proposed by Frebel (2018). A subset of r-II stars $(\sim 30 \%)$ also exhibit an enhancement in Th and U that is referred to as an "actinide boost" (e.g., Hill et al. 2002, Mashonkina et al. 2014, Holmbeck et al. 2018) - a complete explanation for this phenomenon remains elusive. Besides, the detection of radioactive elements like Th (pure r-process, Cowan et al. 2021), in addition to tracing its source of origin, can provide cosmochronometric age determination (see, e.g., Holmbeck et al. 2018 and references therein).

The main aim of this work is to study the elements abundances that have been formed due to n-capture processes in the atmosphere of TYC5594-576-1, with $[\mathrm{Fe} / \mathrm{H}]$ near -3.0. This object is one of the stars from our project to study the sources (sites) of r-process enrichment in the early Galaxy.

\section{Observations and spectrum processing}

The main characteristics of TYC5594-576-1 (HE 15230901) were taken from the SIMBAD database, in particular: Equatorial coordinates: $\alpha=152601 ; \delta=-091139$ (2000) (GAIA DR2); Galactic coordinates: 354.24; +37.83 (2000).

Stellar magnitudes: $\mathrm{B}=12.37 ; \mathrm{V}=11.50$ (SIMBAD); parallax (mas): 0.2772 [0.0434] (GAIA DR2); radial velocity (RV) in $\mathrm{km} / \mathrm{s}=-63.608$ [0.0045] (GAIA DR2); spectral type: CEMP C (Placco et al. 2018) .
One spectrum of this star had been obtained on 18 April 2019 (HJD 2458592.4103) with the 11-m Southern African Large Telescope (SALT) Buckley et al. 2006,O'Donoghue et al. 2006) equipped by fibre-fed dual-beam echellespectrograph HRS (Barnes et al. 2008, Bramall et al. 2010, Bramall et al. 2012, Crause et al. 2014) in the medium resolution mode (R 31000-41000) with a single exposure of 650 s and a high $\mathrm{S} / \mathrm{N}$ ratio near 100-200. HRS allows to provide the spectrum in the blue and red arms over the total spectral range from 3900 to $8700 \AA \AA$. Primary reduction of HRS data, including overscan correction, bias substractions and gain corrections, was done with SALT science pipeline (Crawford et al. 2010). All the data were processed using the software package developed by the authors based on the standard system of astronomical data reduction MIDAS. Further spectra processing, such as the continuum establishment, line depth and equivalent width (EW) measurements, etc., was conducted using the DECH30 software package by G.A.Galazutdinov http://gazinur.com/DECHsoftware.html. The rotational velocity projection was measured by fitting of the observed spectrum with models from Coelho (2014).

\section{Atmosphere parameters determination}

To determine the effective temperature $\mathrm{T}_{\text {eff }}$, we have appreciated the value of $\mathrm{T}_{\text {eff }}$ based on the independence of the iron abundance obtained from given lines from the lower-level potential $\mathrm{E}_{\text {low }}$ of this line (Fig. 1). Gravity $\log \mathrm{g}$ was determined from the ionization equilibrium balance for the Fe I and Fe II abundances. The microturbulent velocity $V_{t}$ was obtained from the condition of independence for $\mathrm{Fe}$ I lines abundances on their equivalent width EW (Fig. 2).

The metallicity $[\mathrm{Fe} / \mathrm{H}]$ was adopted as the iron abundance determined from the Fe I lines. The selection of the parameters was performed using an iterative procedure. Finally, the following parameters were adopted: $\mathrm{T}_{\text {eff }}=$ $4500 \mathrm{~K} ; \log \mathrm{g}=0.75 ; \mathrm{V}_{\mathrm{t}}=2.5 \mathrm{~km} / \mathrm{s}$.

Table 1 represents the comparison results of our data with those from other works. As can be seen in Table 1, there is a good agreement between $\mathrm{T}_{\text {eff }}$, and $[\mathrm{Fe} / \mathrm{H}]$ obtained by different authors. However, some discrepancies are evident for $\log g$ and turbulent velocity $V_{t}$ values.

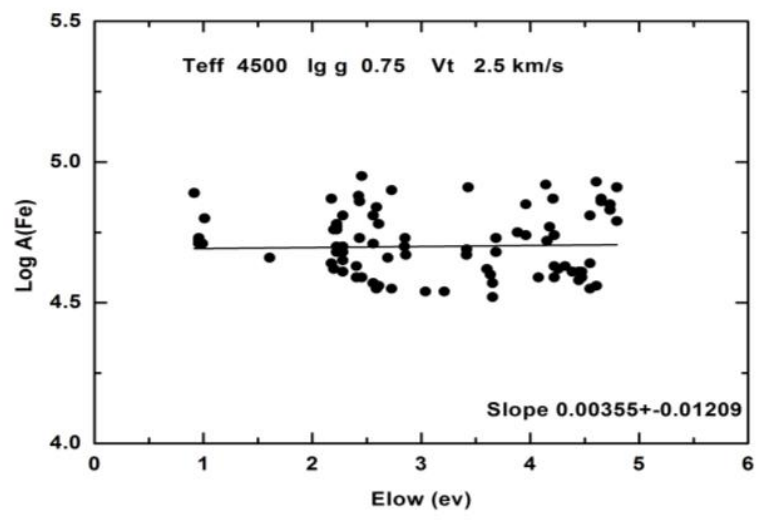

Figure 1: The dependence of $\log \mathrm{A}(\mathrm{Fe} \mathrm{I})$ on $\mathrm{E}_{\text {low }}$ 


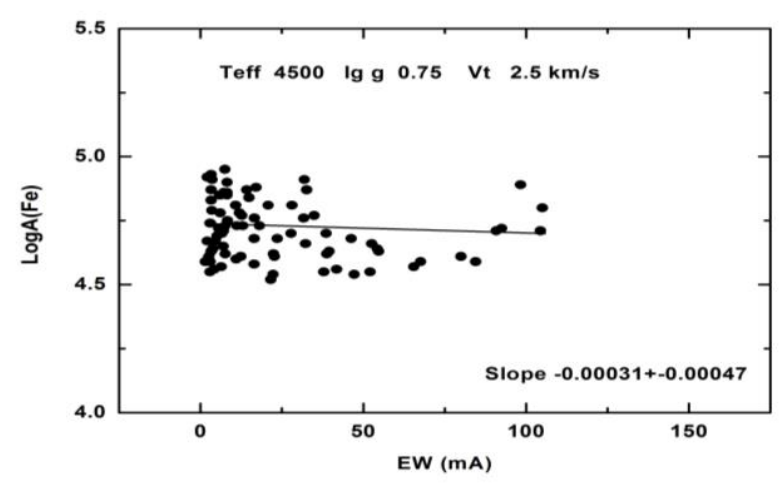

Figure 2: The dependence of $\log \mathrm{A}(\mathrm{FeI})$ on $\mathrm{EW}$

Table 1: Comparison of parameters obtained by different authors

\begin{tabular}{|c|c|l|c|l|}
\hline $\mathbf{T}_{\text {eff }}$ & $\log \mathbf{g}$ & {$[\mathbf{F e} / \mathbf{H}]$} & $\mathbf{V t}$ & reference \\
\hline 4500 & 0.75 & -2.82 & 2.50 & our \\
\hline 4499 & 0.76 & -2.83 & 2.41 & Hansen et al. 2018 \\
\hline 4642 & 0.64 & -3.14 & -- & Placco et al. 2018 \\
\hline 4502 & 0.78 & -3.05 & -- & Beers et al. 2017 \\
\hline 4612 & 0.80 & -2.85 & 2.70 & Frebel et al. 2013 \\
\hline-- & -- & -2.69 & -- & Frebel et al. 2006 \\
\hline
\end{tabular}

In the atmospheres of metal-poor stars the deviations from the Local Thermodynamic Equilibrium (LTE) may influence to the stellar parameters and abundance of iron (see, e.g., Lind et al. 2012). But, for such stars Roederer et al. (2014) shown that the Fe II abundance determined in the LTE approaches agree with those ones under non-LTE approximations within 0.02 dex. The obtained results enabled Roederer et al. (2014) to adopt the iron abundance derived from the Fe II lines as an indicator of the metallicity $[\mathrm{Fe} / \mathrm{H}]$. Our values of the iron abundance obtained from the Fe I and Fe II lines are almost similar, and we used the $\mathrm{Fe} I$ abundance as the metallicity $[\mathrm{Fe} / \mathrm{H}]$ value.

\section{Abundances determination}

The elemental abundances were determined using the LTE approximation and the atmosphere models by Castelli \& Kurucz (2004). The choice of model for each star was made by means of standard interpolation for $\mathrm{T}_{\text {eff }}$ and $\log \mathrm{g}$.

$\mathrm{Na}, \mathrm{Mg}, \mathrm{Al}, \mathrm{Ca}, \mathrm{Sr}, \mathrm{Y}, \mathrm{Zr}, \mathrm{Mo}, \mathrm{Ba}, \mathrm{La}, \mathrm{Ce}, \mathrm{Pr}, \mathrm{Sm}, \mathrm{Eu}$, Gd, Dy, Os, Th abundances were calculated employing the synthetic spectrum method by a new version of the STARSP software (Tsymbal, 1996) and new version of the VALD2018 line list (Kupka et al. 1999), Fe, Si, Sc abundances using EWs of lines and WIDTH9 code by Kurucz. The hyper-fine-structure (HFS) taking into account for abundance determination of $\mathrm{Ba}, \mathrm{La}$, and $\mathrm{Eu}$. For Eu II $4129 \AA$ and $6645 \AA$ lines the data from (Ivans et al. 2006) were used. The carbon abundance was determined using the molecular synthesis fitting in the region of the CH G-band (4300-4330 ÅÅ).

For the $\mathrm{Na}, \mathrm{Mg}, \mathrm{Al}, \mathrm{Sr}$, and $\mathrm{Ba}$ abundances determinations we have used the NLTE corrections computed by Sergei Korotin: the NLTE departures for $\mathrm{Na}, \mathrm{Mg}$ and $\mathrm{Al}$ at $[\mathrm{Fe} / \mathrm{H}] \sim-2.5-3.0$ varied from 0.03 to 0.15 dex depending on $\mathrm{T}_{\text {eff }}$ and $\log \mathrm{g}$ (Korotin et al. 1999, Mishenina et al. 2004, Andrievsky et al. 2008); for the Ba lines at [Fe/H] close to -3.0 was about 0.1 dex (Korotin et al. 2015), for Sr II lines $\sim 0.02$ (S. Korotin, Private communication). For Th $4019 \AA$ line, for Sun it is $0.01 \mathrm{dex}$, and for $[\mathrm{Fe} / \mathrm{H}]$ near -2.5 NLTE correction is about $0.05 \mathrm{dex}$ (Mashonkina et al. 2012).

The spectrum synthesis fitting of the $\mathrm{Mg}, \mathrm{Eu}, \mathrm{Nd}, \mathrm{Gd}$, $\mathrm{Sm}$, and Os lines to the observed profiles for star are shown in Figs. 3, 4.

To determine the systematic errors in the abundance estimates due to uncertainties in the atmospheric parameter determinations, we have derived the elemental abundances for the target star from several models with modified parameters $\left(\delta \mathrm{T}_{\text {eff }}= \pm 100 ; \delta \log \mathrm{g}= \pm 0.2 ; \delta \mathrm{Vt}= \pm 0.1\right)$. The total uncertainty due to the parameter and EW errors for the Fe I and Fe II are 0.11 and 0.12 , respectively. The determination accuracy for other elements varies from 0.10 to $0.18 \mathrm{dex}$.
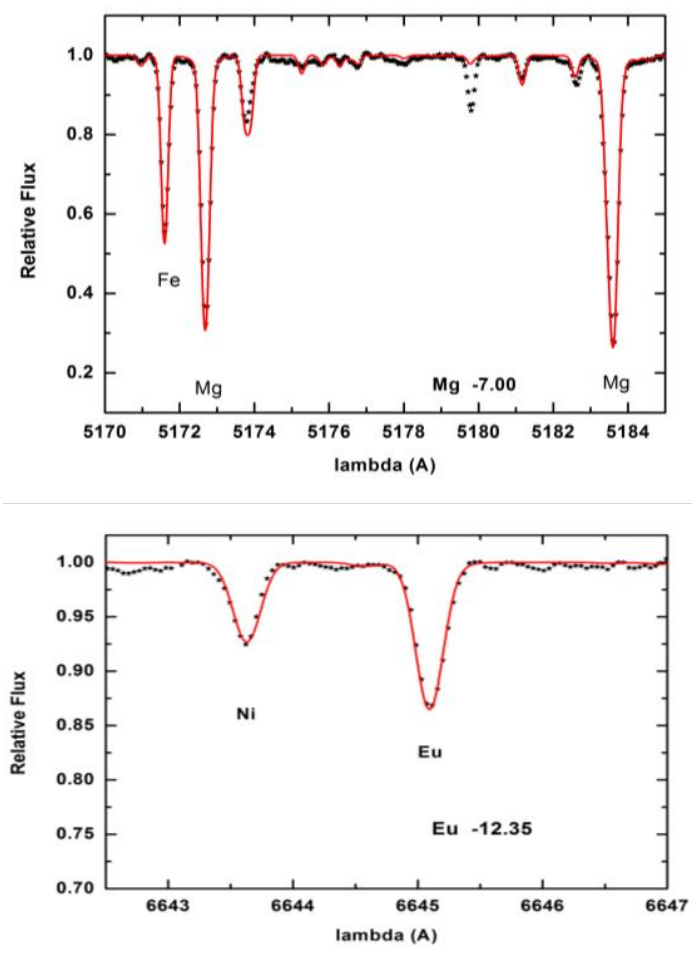

Figure 3: Observed (asterisk) and calculated (solid lines) spectra in the region of $\mathrm{Mg}$ I and Eu II lines.

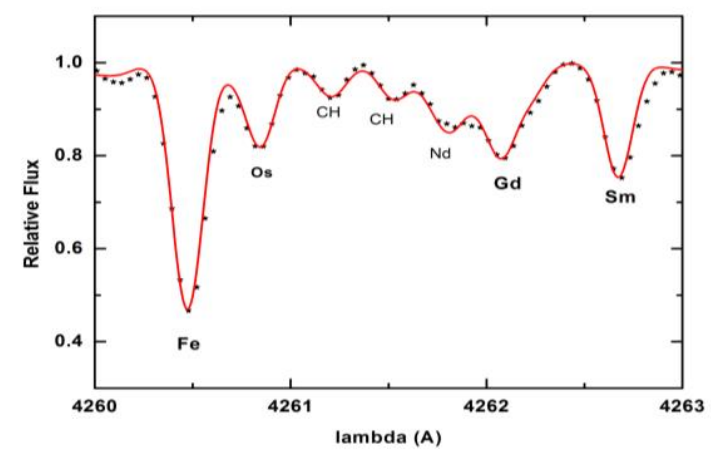

Figure 4: Observed (asterisk) and calculated (solid lines) spectra in the region of Os I $4261 \AA$ line. 
We compared our abundance determinations with those obtained by other authors (Hansen et al. 2018, Placco et al. 2018, Beers et al. 2017, Frebel et al. 2013 Frebel et al. 2006). As seen, our data are in the good agreement with those of other authors (Table 2). But there is a discrepancy for the strontium abundance obtained in our work and the same of Hansen et al. (2018). However, we are confident in the meaning of our $\mathrm{Sr}$ value, which is also confirmed by calculations taking into account deviations from LTE, performed by Sergei Korotin (S. Korotin, Private communication).

The elemental abundances $[\mathrm{El} / \mathrm{Fe}]$ as a function of the relevant atomic numbers for TYC5594-576-1 are depicted in Fig. 5.

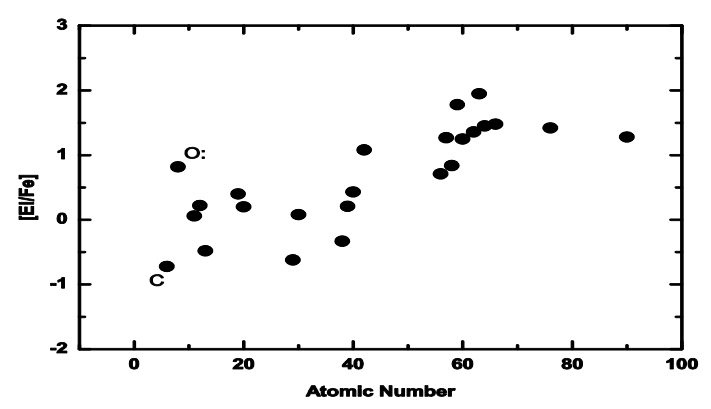

Figure 5: Elemental abundances vs. Atomic Number.

\section{Results and discussions}

We have studied TYC5594-576-1 both from the point of view of the advanced stages of stellar evolution of metal-poor stars, and in the context of n-capture elements enrichment.

\subsection{Stellar evolutionary effects}

Some elements abundances, such as $\mathrm{Li}, \mathrm{CNO}, \mathrm{Na}, \mathrm{Mg}$ and $\mathrm{Al}$ change the course of evolution and by studying them we can estimate the evolutionary effects influence on the atmospheres of clusters and field giants (see, e.g. Charbonnel 1994, 1995, Gratton et al. 2000). Table 2 presents the abundances of the $\mathrm{C}, \mathrm{O}, \mathrm{Na}, \mathrm{Mg}, \mathrm{Al}, \mathrm{Zn}, \mathrm{Sr}, \mathrm{Ba}$ and $\mathrm{Eu}$ obtained in our research, as well as those reported in Frebel et al. (2013), Hansen et al. (2018) and Beers et al. (2017).

Table 2: C, O, Na, Mg, Al, Ca, Zn, Sr, Ba, and Eu abundances

\begin{tabular}{|c|r|c|c|c|}
\hline Elem & Our & $\begin{array}{c}\text { Frebel } \\
\text { et al., } \\
2013\end{array}$ & $\begin{array}{c}\text { Hansen } \\
\text { et al., } \\
2018\end{array}$ & $\begin{array}{c}\text { Beers et } \\
\text { al., 2017 }\end{array}$ \\
\hline$[\mathrm{C} / \mathrm{Fe}]$ & -0.72 & -- & -0.82 & -0.19 \\
\hline$[\mathrm{O} / \mathrm{Fe}]$ & $0.82:$ & -- & -- & -- \\
\hline$[\mathrm{Na} / \mathrm{Fe}]$ & 0.06 & 0.10 & -- & -- \\
\hline$[\mathrm{Mg} / \mathrm{Fe}]$ & 0.22 & 0.30 & -- & -- \\
\hline$[\mathrm{Al} / \mathrm{Fe}]$ & -0.48 & -- & -- & -- \\
\hline$[\mathrm{Ca} / \mathrm{Fe}]$ & 0.20 & 0.26 & -- & -- \\
\hline$[\mathrm{Zn} / \mathrm{Fe}]$ & 0.08 & 0.18 & -- & -- \\
\hline$[\mathrm{Sr} / \mathrm{Fe}]$ & $-\mathbf{0 . 3 3}$ & -- & 0.90 & -- \\
\hline$[\mathrm{Ba} / \mathrm{Fe}]$ & 0.71 & -- & 0.69 & -- \\
\hline$[\mathrm{Eu} / \mathrm{Fe}]$ & 1.85 & -- & 1.70 & -- \\
\hline$[\mathrm{Th} / \mathrm{Fe}]$ & 1.26 & -- & -- & -- \\
\hline
\end{tabular}

Gratton et al. (2000) showed that the abundances of light elements in lower-RGB stars (i.e. stars brighter than those with the first dredge-up luminosity and fainter than the RGB bump) are in concordance with classical evolutionary models. Spite et al. (2006) performed the LTE analysis of several extreme metal-poor (EMP) giants in order to investigate the $\mathrm{CNO}$ abundance and found out a $\mathrm{C}-\mathrm{N}$ anti-correlation that agreement the hypothesis that the surface abundances could be modified by the CNO processed material from the inner regions.

In our investigated star we found the carbon underabundance (Table 2) that may be agreement with the stellar evolution calculations and associated with canonical extra mixing (e.g., Denissenkov \& Pinsonneault 2008 for the CMEP stars). Figure 5 in their paper illustrated variations in the surface $\mathrm{C}$ and $\mathrm{N}$ abundances (black curve) due to canonical extra mixing with the depth $\mathrm{rmix}=0: 045 \mathrm{R} \odot$ and rate $D_{\text {mix }}=0: 04 \mathrm{~K}$ in the RGB model with $\mathrm{M}=0.83$ $\mathrm{M}_{\odot}$ and $\mathrm{Z}=0: 0001$, but the extra mixing depth does not seems to depend strongly on the metallicity (Denissenkov $\&$ VandenBerg 2003). The authors called this universal non-convective mixing process "canonical extra mixing"

We compared our result with calculation of Denissenkov \& Pinsonneault (2008). For that we have computed the value of $\log \mathrm{L} / \mathrm{L}_{\odot}=2.47$ for TYC5594-576-1 based on the classical formula:

$$
\log \mathrm{L} / \mathrm{L} \odot=-2 \log \mathrm{P}-0.4 \mathrm{~m}+0.4 \mathrm{~A}
$$

were $\mathrm{P}$-parallax, $\mathrm{m}$ - stellar magnitude, interstellar reddening $\mathrm{A}=0.14$ (Beers et al. 2017).

With our values of $[\mathrm{C} / \mathrm{H}]=-3.54$ and $\log \mathrm{L} / \mathrm{L} \odot=2.47$ the studied star is located in the black curve which corresponds to canonical extra mixing for non-C-enhanced extremely metal-poor stars with the prediction reported in the afore-mentioned study (their Fig.5).

\subsection{Galactic n-capture element's enrichment}

The obtained pattern of the elements abundances depending on their atomic numbers shows the abundance increases with increasing atomic number (Fig. 5). We have compared also obtained $\mathrm{Sr}, \mathrm{Ba}, \mathrm{Eu}$ abundances with indicators of strong r-process evidence. Our values of $[\mathrm{Eu} / \mathrm{Fe}]=1.85,[\mathrm{Ba} / \mathrm{Eu}]=-1.19,[\mathrm{Sr} / \mathrm{Ba}]=-1.04$ support the definition of this star as enriched with r-process elements (r-I stars: $[\mathrm{Eu} / \mathrm{Fe}]>0.3,[\mathrm{Ba} / \mathrm{Eu}]<0.0,[\mathrm{Sr} / \mathrm{Ba}]>0.5)$. Our studied object exhibits Th overabundance $([\mathrm{Th} / \mathrm{Fe}]=$ 1.26) and can be named as one of the stars with "actinide enhancements" (e.g. Hill et al. 2002, Mashonkina et al. 2014, Holmbeck et al. 2018). The obtained values, including $[\mathrm{Th} / \mathrm{Fe}]=1.28$, may testify in favor of early Galactic enrichment with r-process elements from the merger of neutron stars or black holes (Farouqi et al. 2021). As noted by the aforementioned authors, only two sources may be responsible for the excess of europium and thorium, - there are "two strong r-process sites to neutron star mergers without fast black hole formation and to events where the eject are dominated by black hole accretion disk outflows". 


\section{Conclusion}

For TYC5594-576-1 (HE 1523-0901) we obtained the following:

- Carbon abundance confirms the operating of canonical extra mixing (Denissenkov \& Pinsonneault 2008).

- The abundances of some n-capture elements were determined for the first time, including $\mathrm{Th},[\mathrm{Th} / \mathrm{Fe}]=$ 1.26 .

- Behavior of n-capture element's abundances shows significant trend with atomic number increasing.

- Our values of $[\mathrm{Eu} / \mathrm{Fe}]=1.95,[\mathrm{Ba} / \mathrm{Eu}]=-1.24$, $[\mathrm{Sr} / \mathrm{Ba}]=-1.04$ support the definition of a star as enriched with r-process elements, with low $\mathrm{Sr}$ abundance (r-I stars: $[\mathrm{Eu} / \mathrm{Fe}]>0.3, \quad[\mathrm{Ba} / \mathrm{Eu}]<0.0$, $[\mathrm{Sr} / \mathrm{Ba}]>0.5)$, our $[\mathrm{Sr} / \mathrm{Fe}]=-0.33$.

- The obtained excess of europium and thorium testifies to the early enrichment of the Galaxy with rprocess elements as a result of the merger of neutron stars or black holes.

\section{References}

Andrievsky S. et al.: 2008, $A \& A, \mathbf{4 8 1}, 481$.

Arcones A., Thielemann F-K.: 2013, JPhG, 40, id. 013201

Barnes S. et al.: 2008, SPIE 7014, id. 70140K.

Beers T., Christlieb N.: 2005, ARA\&A, 43, 531.

Beers T. et al.: 2017, ApJ, 835, 81.

Bramall D. et al.: 2010, SPIE 7735, id. 77354F.

Bramall D. et al.: 2012, SPIE 8446, id. 84460A.

Buckley D.A.H., Swart G.P., Meiring J.G.: 2006, SPIE, 6267, id. 62670Z.

Castelli F., Kurucz R.: 2004, ArXiv astro-ph/0405087

Charbonnel C.: 1994, A\&A, 282, 811.
Charbonnel C.:1995, ApJ, 453, 41.

Coelho P.R.T.: 2014, MNRAS, 440, 1027.

Cowan J. et al.: 2021, RvMP, 93, id.015002.

Crause L. et al.: 2014, SPIE 9147, id.91476T.

Crawford S. et al.: 2010, SPIE 7737, id. 773725.

Denissenkov P., Pinsonneault: 2008, ApJ, 679, 1541.

Denissenkov P., VandenBerg D. A.: 2003, ApJ, 593, 509.

Galazutdinov G.: 2007, http://gazinur.com/DECHsoftware.html

Gratton R: 2000, A\&A 354, 169.

Farouqi Kh. et al.: 2021, eprint arXiv:2107.03486

Frebel A.: 2018, ARNPS, 68, 237.

Frebel A. et al.: 2013, ApJ, 769, 57.

Frebel A et al.:2006, ApJ, 652, 1585.

Hansen T. et al. 2018, ApJ, 858, 92.

Hill V. et al.: 2002, $A \& A, \mathbf{3 8 7}, 560$.

Holmbeck E. et al.: 2018, ApJ, 859, id. L24.

Ivans I. et al.: 2006, ApJ, 645, 613.

Korotin S. et al.:1999, ARep 43, 533.

Korotin S. et al.: 2015, $A \& A$ 581, 70.

Kupka F. et al.: 1999, A\&ASuppl., 138, 119.

Lattimer J., Schramm D.: 1974, ApJ, 192, 145.

Lind K. et al.: 2012, MNRAS, 427, 50.

Lippuner J. et al.: 2017, MNRAS, 472, 904.

Mishenina T. et al.: 2004, $A \& A, \mathbf{4 1 8}, 551$.

Mashonkina L. et al..: 2014, $A \& A, \mathbf{5 6 9}, 43$.

Mashonkina L. et al.: 2012, $A \& A, \mathbf{5 4 0}, 98$.

Nishimura N. et al.: 2017, ApJ. 836, 21.

O'Donoghue D. et al., 2006 MNRAS, 372, 151.

Placco V. et al: 2018, AJ, 155, 256.

Roederer I. et al.: 2014, $A J$, 147, 136.

Rosswog S. et al.: 2014, MNRAS, 439, 757.

Simmerer J. et al.: 2004, ApJ, 617, 1091.

Sneden Ch. et al.: 1996, ApJ, 467, 819.

Spite M. et al.: 2006, A\&A, 455, 291.

Spite M. et al.: 2018, $A \& A, \mathbf{6 1 1}, 30$.

Tsymbal V.: 1996, ASP Conf. Ser., 108, 198.

Winteler C. et al.: 2012, ApJ. 750, 22.

Yong D. et al.: 2013, ApJ, 762, 26. 